\title{
55. A Discovery of the Microfossil Faunas from the Otake Formation in Okayama Prefecture, Western Japan ${ }^{\dagger}$
}

\author{
By Kimiyoshi Sada,*) Yukimasa OHo,*) Masashi Inoue,*) \\ Toshio KoIKe, ${ }^{* *}$ Daiji OKADA,**) and Kazuo KANEKo**) \\ (Communicated by Teiichi Kobayashi, M. J. A., May 13, 1985)
}

From the stratigraphical and structural points of view, the Carboniferous and Permian sedimentary rocks and the Upper Triassic sequence in the Hina area of Yoshii, Shitsuki county in Okayama Prefecture, have been studied by Kobayashi (1950), Kobayashi and Hamada (1978), Nakano (1952), Yoshimura (1961), and Sada et al. (1979).

Kobayashi (1950) divided this Paleozoic into the Hina Limestone, Otake Formation, Mihara Formation, Koyama Limestone and Uji Formation in ascending order. Recently Kobayashi and Hamada (1978) reported the Middle or Late Tournasian trilobites from the Hina Limestone. In 1961 Yoshimura studied this Paleozoic and established the Yoshii Group, and divided it into lower Otake and upper Mihara Formations, but its geologic age has been undetermined by fossil.

Recently we have studied their stratigraphy and discovered the conodonts and radiolarians from the Otake Formation. Its lower member is composed of fine to medium grained sandstones and alternating beds of sandstones and mudstones and its upper member of thick cherts. The Mihara Formation overlying the Otake Formation consists of sandstone and mudstone alternation.

We consider the conodonts and radiolaria from the upper Otake cherts are useful for age determination. The fossils and their localities are as follows: Loc. 81133 Hindeodus typicalis (Sweet) $\mathrm{Pa}$ element, Loc. 81154 Neogondolella spp., Loc. 81155 ? Diplognathodus sp. Pb element, Loc. 81163 Neogondolella spp., Loc. YS101 Albaillella sp. D of Ishiga et al., Loc. YS107 Hindeodus sp., Loc. YS109 Albaillella sp. D of Ishiga et al. and Paronaella sp., Loc. YS110 Albaillella sp. D of Ishiga et al., Loc. YS119 Paronaella sp. and Neogondolella sp., Loc. YS195 Hindeodus sp., and Loc. YS233 Neogondolella sp.

Hindeodus typicalis (Sweet) $\mathrm{Pa}$ element was originally described from the Mianwali Formation of Chhidru Nala in Salt Range, West Pakistan. It was reported also by Igo (1981) from the Permian Karasawa Limestone in Kuzuu town, Tochigi Prefecture. Neogondolella spp. are of Permian type. Albaillella sp. D of Ishiga et al. (1982) is thought to be a Middle Permian good indicator. The Otake Formation characterized by the conodonts and radiolaria is regarded as the Middle Permian, and is correlated with the thick cherts of the Middle Permian Notabiyama Formation (Oho, 1985) which thrust over the Upper Permian Maedani Formation in the northern part of the Taishaku Limestone upland in Hiroshima Prefecture.

†) Supported by the Grant-in-Aids for Scientific Research from the Ministry of Education, Science and Culture of Japan.

*) Department of Environmental Sciences, Faculty of Integrated Arts and Sciences, Hiroshima University.

**) Department of Geology, Faculty of Education, Yokohama National University. 


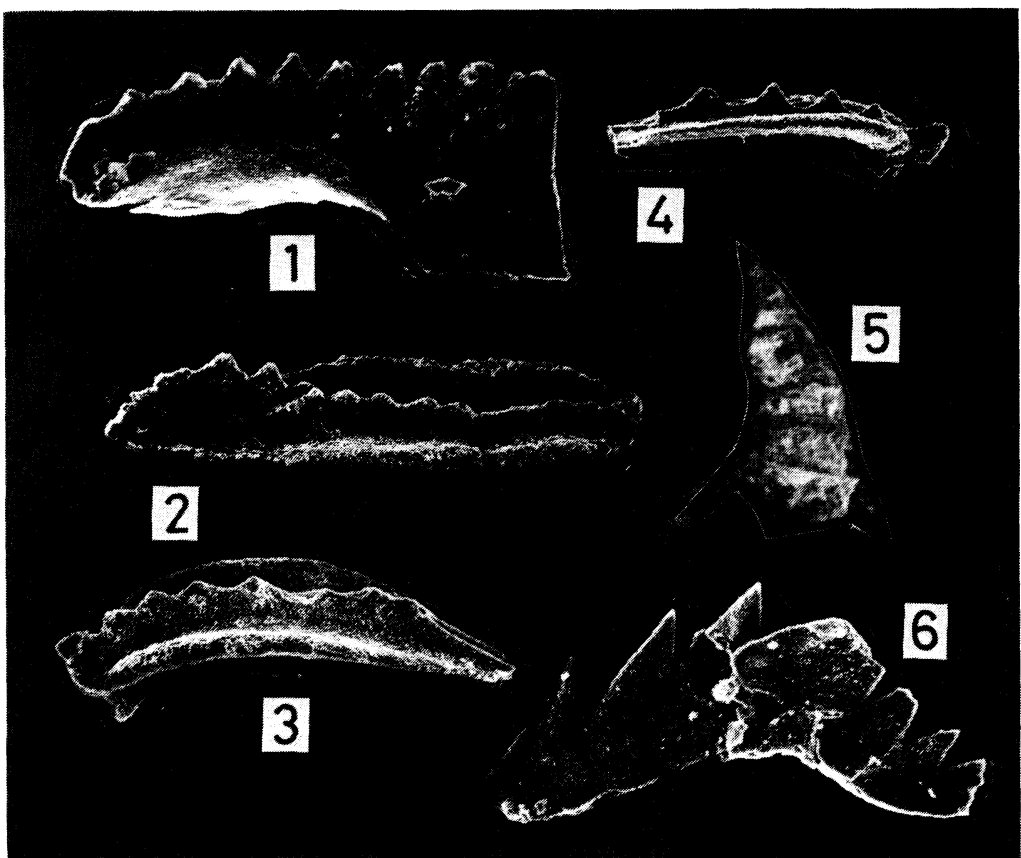

Figs. 1-6. 1: Hindeodus typicalis (Sweet) $\mathrm{Pa}$ element, lateral view, $\times 180$, Loc. Y81133. 2-4: Neogondolella spp. 2: Oblique oral view, $\times 75$, Loc. Y81154. 3 : Oblique oral view, $\times 100$, Loc. Y81163. 4: Lateral view, $\times 100$, Loc. Y81154. 5 : Albaillella sp. D of Ishiga et al., $\times 120$, Loc. YS101. 6: ? Diplognathodus sp. $\mathrm{Pb}$ element, lateral view, $\times 180$, Loc. Y81155.

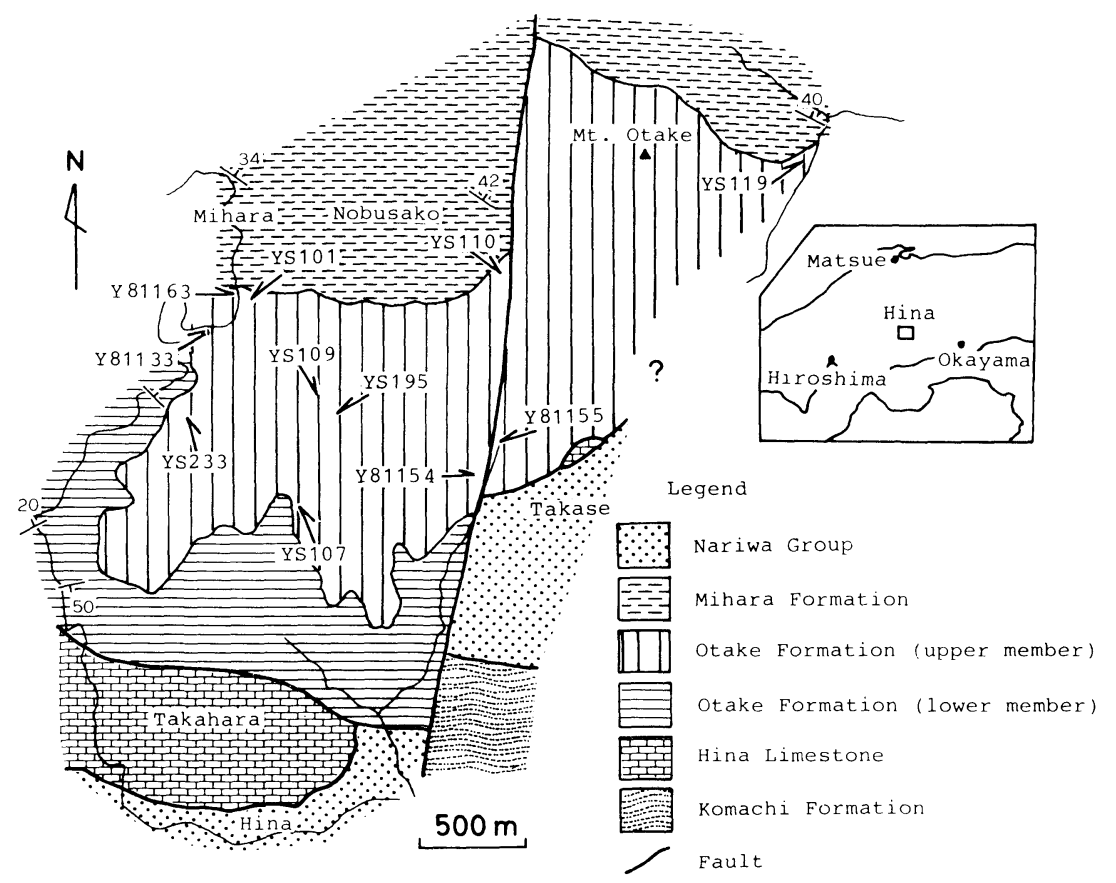

Fig. 7. Geologic map of the Hina area in Okayama Prefecture, western Japan. 
The thick Carboniferous cherts are distributed in the Yuki area in Hiroshima Prefecture, to the northwest of Hina and thrust over the non-calcareous rocks with the lenses of cherts comprising the Permian conodonts. The Carboniferous cherts contain abundant conodonts indicating the Morrowan to the possible Desmoinesian. The Carboniferous conodont faunas consist of Ozarkodina sp. Pa element (=Spathognathodus campbelli Rexford, Hindeodus sp. Pa element (=Anchignathodus minutus (Ellison)), Idiognathoides sulcatus sulcatus Higgins and Bouckaert, Neognathodus bassleri symmetricus (Lane), etc. The conodont faunas of the Yuki area are not in same age to the Otake faunas of Hina.

Now it is concluded that the thick chert strata accompanied with the noncalcareous rocks in the so-called "Kibi highland" in Okayama and Hiroshima Prefectures are of Morrowan to possible Desmoinesian age and of Permian age.

Acknowldgement. We express our sincere gratitude to Professor Emeritus Teiichi Kobayashi, M. J. A., of the University of Tokyo for his kind advice and giving us the facilities to publish this paper.

\section{References}

Igo, H. (1981) : Permian conodont biostratigraphy of Japan. Palaeont. Soc. Japan. Spec. Papers, no. 24, pp. 1-50, pls. 1-12.

Ishiga, H., Kito, T., and Imoto, N. (1982): Middle Permian radiolarian assemblages in the Tamba district and an adjacent area, Southwest Japan. Earth Science, 39(5), 272-281.

Kobayashi, T. (1950) : Regional Geology of Japan-Chugoku District. Asakura Shoten, pp. 1-249 (in Japanese).

Kobayashi, T., and Hamada, T. (1978) : On some Lower Carboniferous Trilobites from the Hina Limestone, Okayama Prefecture, West Japan. Proc. Japan Acad., 54B, 5-9.

Nakano, M. (1952) : Geology of Kyowa-mura district, Shitsuki-gun, Okayama Prefecture with special reference to the recent information on the Paleozoic and Mesozoic. Geol. Rep., Hiroshima Univ., no. 2, pp. 15-36 (in Japanese with English abstract).

Oho, Y. (1985): A thrust in the non-calcareous rocks in the northern part of the Taishaku upland, Hiroshima Prefecture, western Japan. Jour. Geol. Soc. Japan, 91 (2), 109-119 (in Japanese with English abstract).

Sada, K., Hide, K., and Fujimoto, M. (1979) : Preliminary report of the stratigraphy and the geologic structure of the Hina Limestone in Okayama Prefecture, Japan. Mem. Fac. Integr. Arts and Sci. Hiroshima Univ., ser. IV, vol. 4, pp. 15-21 (in Japanese with English abstract).

Yoshimura, N. (1961) : Geological studies of the Paleozoic Groups in the Oga Plateau, central Chugoku, Japan. Geol. Rep. Hiroshima Univ., no. 10, pp. 1-36 (in Japanese with English abstract). 